\title{
Effect of ascorbic acid on urinary hydroxyproline of children receiving corticosteroids
}

\author{
D. LIAKAKOS, D. G. IKKOS, P. VLACHOS, K. NTALLES, and Сн. COULOURIS \\ From the 2nd Department of the Aglaia Kyriakou Children's Hospital, and the Department of Endocrinology and \\ Radioisotopes, Evangelismos Hospital, Athens, Greece
}

\begin{abstract}
Liakakos, D., Ikkos,. D. G., Vlachos, P., Ntalles, K., and Coulouris, Ch. (1974). Archives of Disease in Childhood, 49, 400. Effect of ascorbic acid on urinary hydroxyproline of children receiving corticosteroids. Oral administration of ascorbic acid, $0.5 \mathrm{~g}$ every 8 hours for a period of 4 days, had no effect on the urinary hydroxyproline excretion of 7 healthy children aged 8 to 14 years. When the same medication was given to 8 children aged 9 to 14 years who were receiving large doses of prednisolone $(2 \mathrm{mg} / \mathrm{kg}$ per $24 \mathrm{hr}$ ) for a period of at least 15 days before as well as during ascorbic acid administration, a rise in the urinary hydroxyproline excretion was observed (from a mean value of $44 \pm 4 \cdot 1$ SE before to $67 \pm 4 \cdot 6$ $\mathrm{mg} / 24 \mathrm{hr}$ on the 4 th day of ascorbic acid administration, $\mathrm{P}<0.001$ ). Urinary hydroxyproline excretion of 3 children 4 days after stopping ascorbic acid administration, while still on prednisolone, had returned to the level observed before ascorbic acid. It is concluded that large doses of ascorbic acid can, under acute conditions, neutralize the inhibitory action of corticosteroids on new collagen formation.
\end{abstract}

The adverse skeletal effects of long-term, continuous administration of pharmacological doses of corticoids-manifested by osteoporosis and in children by growth retardation as well-constitute one of the principal side-effects of corticoids that limit their therapeutic application (Travis and Sayers, 1967; Forsham, 1968; Rose, 1970).

Although the exact mechanism of the bone action of corticoids is unclear, it is known that corticoid administration is followed by a decrease in the formation of collagen (Siuko, Sävelä, and Kulonen, 1959; Kivirikko, 1963), and this is shown by a decrease in the urinary hydroxyproline excretion in children (Kibrick et al., 1968; Liakakos et al., 1971). The significance of ascorbic acid in the formation of collagen has been known for a long time (Wolbach and Howe, 1926; Hunt, 1941; Gould and Woessner, 1957) and more recently it has been shown that ascorbic acid can neutralize the inhibitory action of different substances, e.g. puromycin, on new collagen formation (Jeffrey and Martin, 1966a).

We here report a study of the effect of large doses of ascorbic acid on the inhibitory action of corticoids on new collagen formation in children.

Received 23 October 1973.

\section{Material and methods}

The material of the present study consisted of two groups of children. Group A (control group) comprised 7 children ( 4 males and 3 females), aged 8 to 14 years, who were in hospital for minor ailments and were receiving no treatment. Group B (prednisolone group) comprised 4 males and 4 females, aged 9 to 14 years, of whom 6 had acute rheumatic fever and 2 had nephrosis (Table II). All children of group B were treated with prednisolone at a dose of $2 \mathrm{mg} / \mathrm{kg}$ per $24 \mathrm{hr}$ for at least 15 days before the study, as well as during the present study.

All children of both groups received for 4 days ascorbic acid orally, at a dose of $0.5 \mathrm{~g}$ every 8 hours. Collections of 24-hour urine for measurements of hydroxyproline excretion were performed on the day before, and on the last (4th) day of, ascorbic acid administration. In 3 of the children in group B (Cases 8-10 in Table II) 24-hour urine samples were also collected on the 4th day after discontinuation of ascorbic acid administration.

On the day before and on the day of collection of urine samples a diet free of gelatin, meat, and fish was given to all children. The urines were collected under toluol and stored at $-25^{\circ} \mathrm{C}$ until analysed for total hydroxyproline content by the method of Kivirikko, Laitinen, and Prockop (1967).

The statistical analysis of the results used standard techniques, as described by Trichopoulos (1971) and Snedecor and Cochran (1971). 


\section{Results}

he results of the present study are summarized 'ables I and II for groups A and B, respectively, in the Fig.

\section{TABLE I}

lary hydroxyproline excretion of healthy children up $A$ ) before and during administration of ascorbic acid ( $0.5 \mathrm{~g}$ every 8 hours)

\begin{tabular}{|c|c|c|c|c|}
\hline \multirow{2}{*}{ e no. } & \multirow{2}{*}{ Sex } & \multirow{2}{*}{ Age (yr) } & \multicolumn{2}{|c|}{$\begin{array}{l}\text { Urinary hydroxyproline } \\
(\mathrm{mg} / 24 \mathrm{hr})\end{array}$} \\
\hline & & & Before* & $\begin{array}{l}\text { During* } \\
\text { (4th day) }\end{array}$ \\
\hline $\begin{array}{l}1 \\
2 \\
3 \\
4 \\
5 \\
6 \\
7 \\
\text { an val }\end{array}$ & $\begin{array}{l}\mathbf{F} \\
\mathbf{F} \\
\mathbf{F} \\
\mathbf{M} \\
\mathbf{M} \\
\mathbf{M} \\
\mathbf{M}\end{array}$ & $\begin{array}{r}8 \\
9 \\
10 \\
11 \\
11 \\
13 \\
14\end{array}$ & $\begin{array}{r}44 \\
41 \\
48 \\
50 \\
51 \\
66 \\
92 \\
56 \\
6 \cdot 7\end{array}$ & $\begin{array}{r}39 \\
22 \\
50 \\
52 \\
46 \\
70 \\
101 \\
54 \\
9 \cdot 5\end{array}$ \\
\hline
\end{tabular}

fore or during administration of ascorbic acid.

$s$ shown in Table I ascorbic acid administration $\mathrm{g} / \mathrm{kg} \mathrm{8-hourly}$ for 4 days) to the children of the rol group (group A) had no effect on the urinary roxyproline excretion, and the small changes :rved (increase in 4 and decrease in 3) were not ificant.

he same treatment resulted in an increase of the ary hydroxyproline excretion of all children iving prednisolone (group B, Table II), the rence of the values before and after ascorbic being highly significant by the paired t-test : 5.919, $\mathrm{P}<0 \cdot 001$ ).

he mean urinary hydroxyproline excretion of the Iren of group B on the 4th day of ascorbic acid inistration $(67 \pm 4.6 \mathrm{mg} \mathrm{SE}$ per $24 \mathrm{hr}$ ) was :oximately $52 \%$ greater than before ascorbic acid $54.1 \mathrm{mg} \mathrm{SE}$ per $24 \mathrm{hr}$ ) and did not differ ificantly $(P>0.05)$ from the control value of tp A $(56 \pm 6 \cdot 7 \mathrm{mg} \mathrm{SE}$ per $24 \mathrm{hr}$ ).

he urinary hydroxyproline values on the 4th day : discontinuing ascorbic acid in Cases 8-10 of ip B (Table II) were lower than during ascorbic , and were quite similar to the control values of e subjects in all 3 cases.

\section{Discussion}

ydroxyproline, formed by hydroxylation of ine (Stetten and Schoenheimer, 1944; Stetten, '; Prockop, Peterkofsky, and Udenfriend, 1962) is found exclusively in collagen (Neuman and Logan, 1950) and the amount of urinary hydroxyproline excretion, free and peptide bound, on a hydroxyproline-free diet constitutes a reliable index of collagen metabolism (Prockop and Kivirikko, 1967). For example, children (Ziff et al., 1956; Anderson, Bannister, and Tomlinson, 1965) and young experimentual animals (Martin, Mergenhagen, and Prockop, 1961; Kivirikko and Laitinen, 1965; Smith and Allison, 1965) excrete more hydroxyproline than adult subjects and grown-up animals, respectively. A relation between urinary hydroxyproline and growth rate has also been shown (Jasin et al., 1962; Zorab et al., 1970).

Administration of corticoids results in a decreased formation of collagen (Siuko et al., 1959; Kivirikko, 1963), with a decreased urinary hydroxyproline excretion (Kibrick et al., 1968; Liakakos et al., 1971) associated with inhibition of growth in children (Van Metre and Pinkerton, 1959; Falliers et al., 1963; Blodgett et al., 1965).

Because of the well-known large variations of the urinary hydroxyproline values in children (Ziff $e t$ al., 1956) and the small number of subjects studied by us, no statistically significant difference $(t=1 \cdot 55$, $P>0.05)$ could be found between the subjects of the two groups with respect to the urinary hydroxyproline values before ascorbic acid. As shown, however, in the Fig., subjects receiving prednisolone tended to have lower values than the control

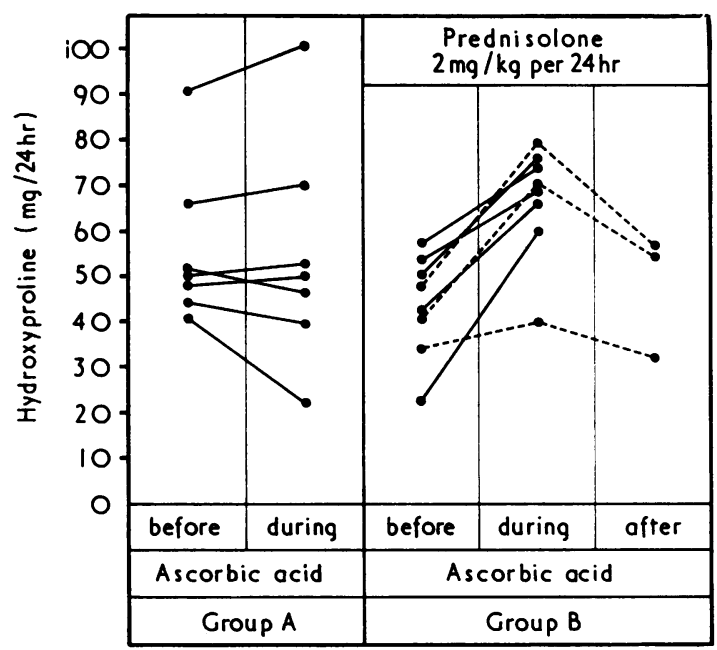

FIG.-Urinary hydroxyproline excretion of healthy children (group $A$ ) and children on prednisolone for at least 15 days ( $2 \mathrm{mg} / \mathrm{kg}$ per $24 \mathrm{hr}$ ) (group $B$ ) before, during (4th day), and after (4th day) oral administration of ascorbic acid $(0.5 \mathrm{~g}$ every 8 hours $)$. 
TABLE II

Urinary hydroxyproline excretion before, during, and after administration of ascorbic acid ( $0.5 \mathrm{~g}$ every 8 hours) to children treated with prednisolone $(2 \mathrm{mg} / \mathrm{kg}$ per $24 \mathrm{hr}$ ) for at least 15 days before as well as during the present study (group B)

\begin{tabular}{|c|c|c|c|c|c|c|c|}
\hline \multirow{2}{*}{ Case no. } & \multirow{2}{*}{ Sex } & \multirow{2}{*}{ Age (yr) } & \multirow{2}{*}{ Diagnosis } & \multirow{2}{*}{$\begin{array}{c}\text { Prednisolone } \\
\text { (2 } \mathrm{mg} / \mathrm{kg} \text { per } 24 \mathrm{hrs}) \\
\text { for }\end{array}$} & \multicolumn{3}{|c|}{$\begin{array}{l}\text { Urinary hydroxyproline } \\
(\mathrm{mg} / 24 \mathrm{hr})\end{array}$} \\
\hline & & & & & Before ${ }^{\star}$ & $\begin{array}{l}\text { During* } \\
(4 \text { th dy) }\end{array}$ & $\begin{array}{l}\text { After } \\
(4 \text { th dy) }\end{array}$ \\
\hline $\begin{array}{l}8 \\
9 \\
10 \\
11 \\
12 \\
13 \\
14 \\
15 \\
\text { Mean } \\
\text { SE }\end{array}$ & $\begin{array}{l}\mathrm{F} \\
\mathrm{F} \\
\mathrm{M} \\
\mathrm{F} \\
\mathrm{F} \\
\mathrm{M} \\
\mathrm{M} \\
\mathrm{M}\end{array}$ & $\begin{array}{r}9 \\
9 \\
10 \\
10 \\
11 \\
12 \\
12 \\
14\end{array}$ & $\begin{array}{l}\text { Rheumatic fever } \\
\text { Nephrosis ", } \\
\text { ", } \\
\text { Rheumatic fever } \\
\text { ", ", } \\
\text { ", }\end{array}$ & $\begin{array}{l}18 \mathrm{dy} \\
18 ", \\
20 ", \\
20 ", \\
20 " \\
15 " \\
15 " \\
15 "\end{array}$ & $\begin{array}{r}40 \\
34 \\
48 \\
51 \\
22 \\
57 \\
54 \\
41 \\
44 \\
4 \cdot 1\end{array}$ & $\begin{array}{r}74 \\
38 \\
78 \\
76 \\
60 \\
74 \\
68 \\
67 \\
67 \\
4 \cdot 6\end{array}$ & $\begin{array}{l}54 \\
32 \\
55\end{array}$ \\
\hline
\end{tabular}

$\star$ Before, during, or after administration of ascorbic acid.

subjects. Thus, values larger than $60 \mathrm{mg} / 24 \mathrm{hr}$ were found in 2 of the 7 controls and in none of the 8 subjects of the prednisolone group.

The exact mechanism of the inhibitory action of corticoids on collagen formation has not been fully elucidated. The view that corticoids inhibit hydroxyproline synthesis, possibly during the hydroxylation of proline (Chvapil, 1959) is supported by the experimental results of Daughaday and Mariz (1962), who showed that addition of cortisol to cartilage culture in vitro inhibited hydroxylation of proline to hydroxyproline and, consequently, new collagen formation.

Although the specific role of ascorbic acid on collagen synthesis has been known for a long time (Wolbach and Howe, 1926; Hunt, 1941; Gould and Woessner, 1957), only in recent years has it been shown that its primary effect is on hydroxylation of proline after formation of protocollagen by peptide binding (Jeffrey and Martin, 1966a; Udenfriend, 1966; Comstock, Gribble, and Udenfriend, 1970) and that ascorbic acid acts as a co-factor of the specific enzyme (Hutton, Tappel, and Udenfriend, 1966; Juva and Prockop, 1966).

Jeffrey and Martin (1966b) studied the influence of ascorbic acid depletion on the growth of embryonic chick tibias in vitro. Of the parameters studied, the rate of collagen synthesis was particularly sensitive to ascorbic acid deficiency. After 4 days in culture without ascorbic acid, collagen synthesis virtually ceased. Addition of ascorbic acid to previously depleted tibias restored the rate of collagen synthesis to normal within 12 hours.

The same authors reported that puromycin inhibited the synthesis of peptide-bound hydroxyproline. Simultaneous addition of ascorbic acid and puromycin to bones prelabelled with ${ }^{14} \mathrm{C}$ proline increased the amount of peptide-bound hydroxyproline. Peck, Birge, and Brandt (1967), working with cultures in vitro of isolated bone cells, arrived at similar results.

These facts, together with reports that ascorbic acid can hamper the inhibitory action of different substances on the hydroxylation of proline (Jeffrey and Martin, 1966a) led us to consider the possibility that large doses of ascorbic acid might eventually impede the inhibitory action of corticoids on new collagen formation.

Such a hypothesis is in keeping with the increased urinary hydroxyproline we observed after administration of ascorbic acid to children receiving large doses of prednisolone, from which it appeared that the inhibitory action of corticoids on new formation of collagen could be neutralized by large doses of ascorbic acid, at least under the conditions and for the duration of these studies.

That these results were not due to errors of methodology, i.e. interference of ascorbic acid in the urine on the determinations of urinary hydroxyproline, is proved by the fact that hydroxyproline excretion was unchanged during ascorbic acid administration to children not receiving prednisolone (Table I).

Although measurements of blood ascorbic acid levels were not performed, the possibility that patients treated with prednisolone were suffering from a subclinical deficiency of ascorbic acid, due to their illness and possible anorexia, and that the subsequent rise in total hydroxyproline after 
ascorbic acid was due to the treatment of this mild deficiency, seems highly improbable in view of the immediate drop of the urinary hydroxyproline values after discontinuation of the ascorbic acid, i.e. at a moment when subclinical ascorbic acid deficiency can be excluded.

It remains to be seen whether continuous administration of large doses of ascorbic acid during long-term therapy with corticoids will be able to prevent the skeletal side-effects of corticosteroid treatment.

\section{REFERENCES}

Anderson, J., Bannister, D. W., and Tomlinson, R. W. S. (1965) Total urinary hydroxyproline excretion in normal human subjects. Clinical Science, 29, 583.

Blodgett, F. M., Burgin, L., Iezzoni, D., Gribetz, D., and Talbot, N. B. (1965). Effects of prolonged cortisone therapy on the statural growth, skeletal maturation and metabolic status of children. New England fournal of Medicine, 254, 636.

Chvapil, M. (1959). Changes in free and bound hydroxyproline during the development of normal and cortisone-treated chick embryos. Physiologia Bohemoslovenica, 8, 186.

Comstock, J. P., Gribble, T. J., and Udenfriend, S. (1970). Further study on the activation of collagen proline hydroxylase in cultures of L-929 fibroblasts. Archives of Biochemistry and Biophysics, 137, 115.

Daughaday, W. H., and Mariz, I. K. (1962). Conversion of prolineU-C 14 to labelled hydroxyproline by rat cartilage in vitro: effects of hypophysectomy, growth hormone, and cortisol. Fournal of Laboratory and Clinical Medicine, 59, 741.

Falliers, C. J., Tan, L. S., Szentivanyi, J., Jorgensen, J. R., and Bukantz, S. C. (1963). Childhood asthma and steroid therapy as influences on growth. American fournal of Diseases of Children, 105, 127.

Forsham, P. H. (1968). The adrenal cortex. In Textbook of Endocrinology, 4th ed., p. 287. Ed. by R. H. Williams. Saunders, Philadelphia.

Gould, B. S., and Woessner, J. F. (1957). Biosynthesis of collagen. The influence of ascorbic acid on the proline, hydroxyproline, glycine and collagen content of regenerating guinea pig skin. Fournal of Biological Chemistry, 226, 289.

Hunt, A. H. (1941). The role of vitamin C deficiency in wound healing. British fournal of Surgery, 28, 436.

Hutton, J. J., Tappel., A. L., and Udenfriend, S. (1966). Requirements for a-ketoglutarate, ferrous iron and ascorbate by collagen proline hydroxylase. Biochemical and Biophysical Research Communications, 24, 179.

Jasin, H. E., Fink, C. W., Wise, W., and Ziff, M. (1962). Relationship between urinary hydroxyproline and growth. fournal of Clinical Investigation, 41, 1928.

Jeffrey, J. J., and Martin, G. R. (1966a). The role of ascorbic acid in the biosynthesis of collagen. II. Site and nature of ascorbic acid participation. Biochimica et Biophysica Acta, 121, 281.

Jeffrey, J. J., and Martin, G. R. (1966b). The role of ascorbic acid in the biosynthesis of collagen. I. Ascorbic acid requirement by embryonic chick tibia in tissue culture. Biochimica et Biophysica Acta, 121, 269.

Juva, K., and Prockop, D. J. (1966). Synthesis of hydroxyproline in vitro by the hydroxylation of a polypeptide precursor of collagen. In Biochimie et Physiologie du Tissu Conjonctif, p. 417. Ed. by P. Compte. Société Ormeco et Imprimerie du Sud-Est à Lyon, Lyon.

Kibrick, A. C., Power, H. L., Sevendal, E., and Milhorat, A. T. (1968). Prednisone effect on urinary excretion of hydroxyproline in patients with muscular dystrophy. fournal of Clinical Endocrinology and Metabolism, 28, 1113.
Kivirikko, K. I. (1963). Hydroxyproline-containing fractions in normal and cortisone-treated chick embryos. Acta Physiologica Scandinavica, 60, Suppl. 219, 1.

Kivirikko, K. I., and Laitinen, O. (1965). Effect of cortisone on the hydroxyproline in the serum and urine of young rats. Acta Physiologica Scandinavica, 64, 356.

Kivirikko, K. I., Laitinen, O., and Prockop, D. J. (1967). Modification of a specific assay for hydroxyproline in urine. Analytical Biochemistry, 19, 249.

Liakakos, D., Vlachos, P., Anoussakis, C., and Keletsekis, I. (1971). The effect of continuous and intermitrent prednisolone administration on the amount of urinary hydroxyproline in children. Archives of the Hellenic Paediatric Society, 34, 161.

Martin, G. R., Mergenhagen, S. E., and Prockop, D. J. (1961) Influence of scurvy and lathyrism (odoratism) on hydroxyproline excretion. Nature (London), 191, 1008.

Neuman, R. E., and Logan, M. A. (1950). The determination of collagen and elastin in tissues. Fournal of Biological Chemistry, 186, 549.

Peck, W. A., Birge, S. J., Jr., and Brandt, J. (1967). Collagen synthesis by isolated bone cells: stimulation by ascorbic acid in vitro. Biochimica et Biophysica Acta, 142, 512.

Prockop, D. J. and Kivirikko, K. I. (1967). Relationship of hydroxyproline excretion in urine to collagen metabolism. Annals of Internal Medicine, 66, 1243.

Prockop, D. J., Peterkofsky, B., and Udenfriend, S. (1962) Studies on the intracellular localization of collagen synthesis in the intact chick embryo. Fournal of Biological Chemistry, 237, 1581.

Rose, G. A. (1970). Irreversibility of osteoporosis. In Osteoporosis, p. 123. Ed. by U. S. Barzel. Grune and Stratton, New York.

Siuko, H., Săvelä, J., and Kulonen, E. (1959). Effect of hydrocortisone on the formation of collagen in guinea pig skin. Acta Endocrinologica, 31, 113.

Smith, Q. T., and Allison, D. J. (1965). Skin and femur collagens and urinary hydroxyproline of cortisone-treated rats. Endocrinology, 77, 785.

Snedecor, G. W., and Cochran, W. G. (1971). Statistical Methods, p. 32. Iowa University Press, Ames, Iowa.

Stetten, M. R. (1949). Some aspects of the metabolism of hydroxyproline, studies with the aid of isotopic nitrogen. Fournal of Biological Chemistry, 181, 31.

Stetten, M. R., and Schoenheimer, R. (1944). The metabolism of 1 (-)-proline studied with the aid of deuterium and isotopic nitrogen. Fournal of Biological Chemistry, 153, 113.

Travis, R. H., and Sayers, G. (1967). Adrenocorticotropic hormone; adrenocortical steroids and their synthetic analogs. In The Pharmacological Basis of Therapeutics, p. 1608. Ed. by L. S. Goodman, and A. Gilman. Macmillan, New York.

Trichopoulos, D. (1971). Elements of Medical Statistics, p. 44. Parisianos, Athens.

Udenfriend, S. (1966). Formation of hydroxyproline in collagen. Proline is incorporated into peptides before it is hydroxylated. Science, 152, 1335.

Van Metre, T. E., Jr., and Pinkerton, H. L., Jr. (1959). Growth suppression in asthmatic children receiving prolonged therapy with prednisone and methylprednisolone. fournal of Allergy, 30, 103.

Wolbach, S. B., and Howe, P. R. (1926). Intercellular substances in experimental scorbutus. Archives of Pathology, $1,1$.

Ziff, M., Kirbrick, A., Dresner, E., and Gribetz, H. J. (1956). Excretion of hydroxyproline in patients with rheumatic and non-rheumatic diseases. Fournal of Clinical Investigation, 35, 549.

Zorab, P. A., Clark, S., Harrison, A., and Seel, J. R. (1970). Hydroxyproline excretion and height velocity in adolescent boys. Archives of Disease in Childhood, 45, 763.

Correspondence to Dr. D. G. Ikkos, Department of Endocrinology and Radioisotopes, Evangelismos Hospital, Athens 140, Greece. 